\title{
POTENTIAL USE OF ARCHAEOLOGICAL SNAIL SHELLS FOR THE CALCULATION OF LOCAL MARINE RESERVOIR EFFECT
}

\author{
Carla Carvalho $^{1}$ - Kita Macario ${ }^{2}$ - Maria Isabela De Oliveira ${ }^{2}$ Fabiana Oliveira $^{2}$ • \\ Ingrid Chanca ${ }^{2} \cdot$ Eduardo Alves $^{2} \cdot$ Rosa Souza $^{3} \bullet$ Orangel Aguilera $^{3} \bullet$ Katerina Douka $^{4}$
}

\begin{abstract}
Shellmounds are archaeological sites found across the Brazilian coast and form an important record of the human occupation of this area during the Holocene. The presence of both terrestrial and marine remains within the same archaeological context enables the comparison of different carbon reservoirs. There is only a small number of similar studies for the coast of south-southeastern Brazil. Previous work was based on the analysis of pre-bomb shells from museum collections and paired charcoal/marine shells from archaeological sites. This article assesses the potential use of terrestrial shells as representative of atmospheric carbon reservoir in the calculation of the marine reservoir effect (MRE) of the southeastern Brazilian coast. The presence of both terrestrial and marine shells over several archaeological layers represents a great potential for calculating reservoir corrections and their temporal variation.
\end{abstract}

\section{INTRODUCTION}

Radiocarbon dating of terrestrial organic materials lies on the assumption that the ${ }^{14} \mathrm{C}$ level in the sample is in equilibrium with the corresponding atmospheric carbon reservoir. Many paleoenvironmental, geological, and archaeological studies have used land snail shells to reconstruct occupation history and past climatic and environmental conditions at the sites under study (Xu et al. 2011; Yanes et al. 2011, 2012; Zaarur et al. 2011; Rech et al. 2012; Rakovan et al. 2013).

When dating snails, it is the mineral matrix of the shell, mostly composed of calcium carbonate in the form of aragonite, that is dated. The use of land snails as dating material is restricted to a group of snails that do not incorporate old carbon from limestone or calcareous sediments, which would lead to old apparent ages (Tamers 1970; Evin et al. 1980; Goodfriend and Hood 1983; Goodfriend and Stipp 1983; Yates 1986; Goodfriend 1987; Goodfriend et al. 1999; Zhou et al. 1999; Quarta et al. 2007; Romaniello et al. 2008; Xu et al. 2011).

The biological pathways for the incorporation of old carbon are not well understood. Goodfriend and Hood (1983) suggested that atmospheric $\mathrm{CO}_{2}$, plants, and ${ }^{14} \mathrm{C}$-depleted limestone are the three possible sources of carbon during the formation of aragonite shells in terrestrial gastropods. However, in a recent study there was no difference in the carbonate isotopic composition of Helix aspersa (Müller, 1774) fed with a $\mathrm{CaCO}_{3}$ diet compared to a $\mathrm{CaCO}_{3}$-free diet, suggesting that the most relevant source of carbon is metabolic $\mathrm{CO}_{2}$ from food sources incorporated through direct digestion and breakdown of urea (Stott 2002). The mechanisms of incorporation and distribution of carbon isotopes are not necessarily the same for all terrestrial species (Barnhardt 1992; Stott 2002). Furthermore, there is evidence that the use of $\delta^{13} \mathrm{C}$ to calculate the old carbon effect in terrestrial species is flawed (Xu et al. 2011). For dating purposes, each terrestrial gastropod species should be tested for incorporation of old carbon and discarded if necessary. Some terrestrial gastropods of the most common genera in North America, such as Catinella, Columella, Discus, Gastrocopta, and Succinea, have been shown to yield reliable ${ }^{14} \mathrm{C}$ dates, regardless of the local geologic substrate (Pigati et al. 2010).

\footnotetext{
1. Departamento de Geoquímica, Instituto de Química, Universidade Federal Fluminense, Outeiro São João Batista, s/n, Niterói, 24020-141, RJ, Brazil. Corresponding author. Email: carlacarvalho@geoq.uff.br.

2. Instituto de Física, Universidade Federal Fluminense, Av. General Milton Tavares de Souza, s/n, Niterói, 24210-346, RJ, Brazil.

3. Departamento de Biologia Marinha, Instituto de Biologia, Universidade Federal Fluminense, Outeiro São João Batista, s/n, Niterói, 24020-141, RJ, Brazil.

4. Oxford Radiocarbon Accelerator Unit, University of Oxford, Dyson Perrins Building, South Parks Road, Oxford OX1, UK.
}

Proceedings of the 1st International Radiocarbon in the Environment Conference 18-22 August 2014, Queen's University Belfast, Belfast, Northern Ireland, UK

Edited by Evelyn Keaveney and Paula Reimer 


\section{THE MARINE RESERVOIR EFFECT}

The marine reservoir effect (MRE) is defined as an offset between the marine and atmospheric reservoir ${ }^{14} \mathrm{C}$ content and has an average value of $405 \pm 22{ }^{14} \mathrm{C}$ yr (Hughen et al. 2004), known as the global marine reservoir effect, or $R_{g}$. The MRE has also a local component, a $\Delta \mathrm{R}$ value, that represents the difference between the reservoir age and the mean global age (Stuiver et al. 1986; Stuiver and Braziunas 1993) and takes into account time and space variations, which depend on many factors like the carbon exchange between ocean carbonates and atmospheric $\mathrm{CO}_{2}$, upwelling currents, circulation patterns, and coastal topography (Gordon and Harkness 1992; Ascough et al. 2004). Quantification of the local marine reservoir effect is important in the establishment of accurate archaeological chronologies (Fernandes et al. 2012).

Traditionally, pre-bomb marine shells or pairs of associated archaeological samples, such as marine shells and charcoal from the same depositional context, have been used to determine the difference between the terrestrial and marine carbon reservoirs (Kennett et al. 1997; Culleton 2006; Culleton et al. 2006; Soares and Dias 2006, 2007; Ascough et al. 2009; Russell et al. 2010; Petchey et al. 2013). However, in some archaeological sites, samples of charcoal are scarce or not present at all. In that case, terrestrial gastropods may be used as an alternative, provided that they yield reliable ${ }^{14} \mathrm{C}$ ages.

The aim of this work is to assess the potential use of the gastropod Thaumastus achilles (Pfeiffer, 1852) from the Bulimulidae family as a reliable representative of the atmospheric carbon reservoir in the analysis of the MRE in the southeastern Brazilian coast. Prior to using any land snail taxon in such studies, its reliability has to be evaluated. The incorporation of "old" $\left({ }^{14} \mathrm{C}\right.$-free) material will depend upon the diet of each animal (Rubin et al. 1963). T. achilles is known to feed from trees and shrubs (Breure 1979) and its presence in South America is attested for several thousands of years. Very abundant in the southeastern coast of Brazil, it was collected and eaten regularly by fisher-gatherer populations. The availability of both terrestrial and marine shells found over several archaeological layers presents great potential for calculating MRE corrections from paired samples.

Very few similar studies are available for the coast of Brazil, and these are mostly based on prebomb shells from museum collections. A number of ${ }^{14} \mathrm{C}$ dates of marine shells from the northern coast of Ilha de Santa Catarina $\left(27^{\circ} 30^{\prime} \mathrm{S}, 48^{\circ} 00^{\prime} \mathrm{W}\right)$, in Santa Catarina State, were used to estimate a mean reservoir age using samples with similar ages from a museum collection (Nadal de Masi $2001)$. Charcoal-shell pairs from an archaeological site at Jabuticabeira $\left(27^{\circ} 36^{\prime} \mathrm{S}, 48^{\circ} 60^{\prime} \mathrm{W}\right)$, in Santa Catarina State, were used to estimate a reservoir correction (Eastoe et al. 2002). Angulo et al. (2005) used museum samples and previously published determinations from shells of known age to estimate a reservoir correction considering all available data in the same region (Nadal de Masi 2001; Eastoe et al. 2002). Analyzing museum samples from Ilha do Francês $\left(27^{\circ} 25^{\prime} \mathrm{S}, 48^{\circ} 28^{\prime} \mathrm{W}\right.$ to $\left.27^{\circ} 41^{\prime} \mathrm{S}, 48^{\circ} 29^{\prime} \mathrm{W}\right)$, in Santa Catarina State, and Ilha do Mel $\left(25^{\circ} 30^{\prime} \mathrm{S}, 48^{\circ} 17^{\prime} \mathrm{W}\right.$ to $25^{\circ} 35^{\prime} \mathrm{S}$, $48^{\circ} 23^{\prime} \mathrm{W}$ ), in Paraná State, they obtained $\Delta \mathrm{R}$ values between $112 \pm 41$ and $-55 \pm 41{ }^{14} \mathrm{C}$ yr, with a mean of $33 \pm 24{ }^{14} \mathrm{C}$ yr. Considering previous works, a new $\Delta \mathrm{R}$ mean value was estimated by Angulo et al. (2005) to be $8 \pm 17{ }^{14} \mathrm{C}$ yr for the Brazilian southern and southeastern marine surficial coastal waters. A large range of $\Delta \mathrm{R}$ values was taken into account for this new value, and it should not be representative of such a large coast extension. More recently, Macario et al. (2015) and Alves (2015) obtained $\Delta \mathrm{R}$ values of $-140 \pm 66{ }^{14} \mathrm{C}$ yr for Saquarema $\left(22^{\circ} 55^{\prime} \mathrm{S}, 42^{\circ} 30^{\prime} \mathrm{W}\right)$ and $-127 \pm$ $67{ }^{14} \mathrm{C}$ yr for Rio das Ostras $\left(22^{\circ} 31^{\prime} \mathrm{S}, 41^{\circ} 56^{\prime} \mathrm{W}\right)$, respectively, on the southeastern Brazilian coast. Thus, the purpose of this article is to use paired samples of marine and terrestrial mollusk shells, the former being a food source for fisher-gatherer populations, distributed over several archaeological layers in shellmounds around the coast, as a potential tool for calculating MRE corrections. 


\section{MATERIALS AND METHODS}

In order to investigate the dead carbon incorporation through diet by $T$. achilles, we have ${ }^{14} \mathrm{C}$ dated shells of three recently dead animals collected in Cabo Frio $\left(23^{\circ} 53^{\prime} \mathrm{S}, 42^{\circ} 29^{\prime} \mathrm{W}\right)$, Rio de Janeiro State.

To evaluate the potential use of terrestrial shells as representative of atmospheric carbon reservoir for MRE on the southeastern Brazilian coast, specimens from the Manitiba I shellmound, located in Saquarema ( $\left.22^{\circ} 55^{\prime} 66^{\prime \prime} \mathrm{S}, 42^{\circ} 29^{\prime} 00^{\prime \prime} \mathrm{W}\right)$, Rio de Janeiro State (Figure 1), were selected from the zooarchaeological collection of the National Brazilian Museum at the Rio de Janeiro Federal University (MN-UFRJ). The Manitiba I shellmound, like most of the shellmounds located in the city of Saquarema, is positioned on a sandbank, between the lagoon and the sea, strategically close to marine resources (Kneip 2001). With a total area of $6000 \mathrm{~m}^{2}$, it is the largest shellmound in the region. Excavations in 1999 and 2000 covered an area of $140 \mathrm{~m}^{2}$ and seven archaeological layers were identified, with the base $3.36 \mathrm{~m}$ above the mean sea level. Only two funerary structures were recovered, in contrast to other shellmounds in the same area, with at least 19 funerary structures each. The spatial distribution of artifacts and other archaeological remains characterize this shellmound as a living place with intense domestic and ceremonial activities (Kneip 2001). The available dates for the Manitiba I shellmound vary from $3810 \pm 70$ to $4270 \pm 70$ BP (Kneip 2001).

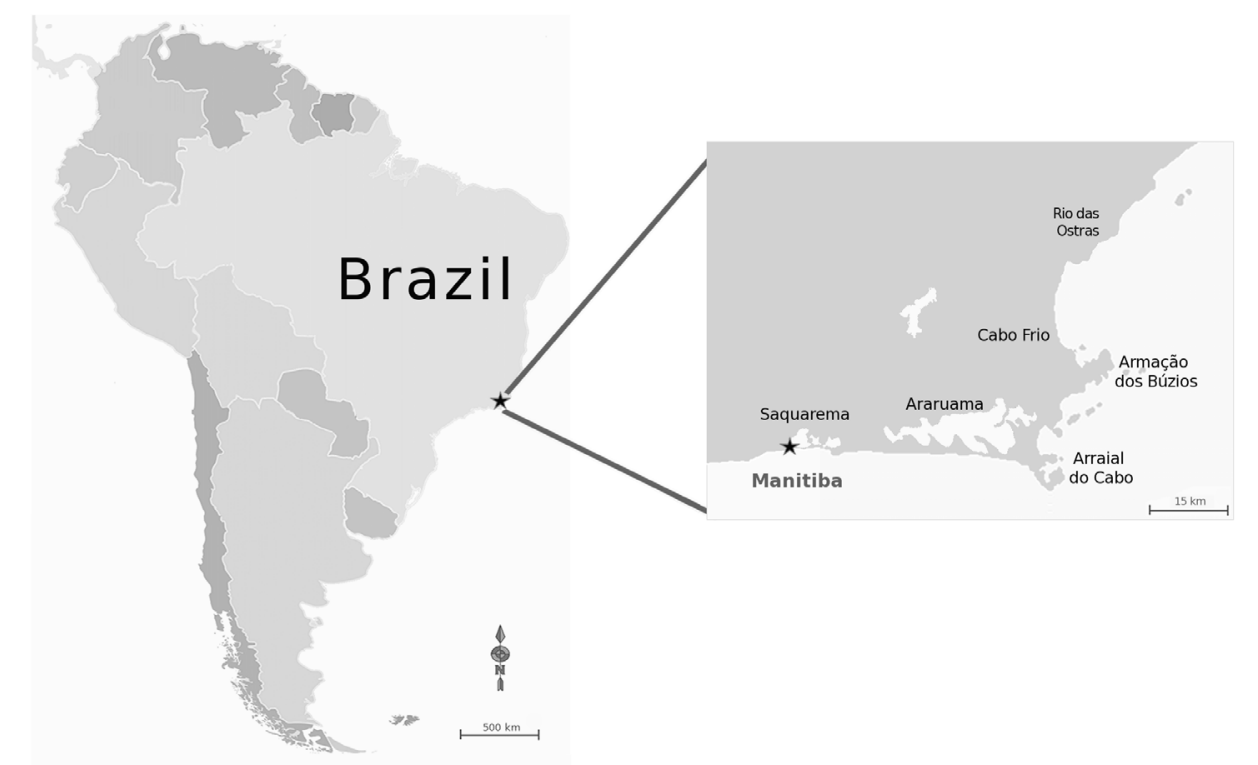

Figure 1 Location of the study area (modified from Macario et al. 2014)

Samples of $T$. achilles shells, charcoal from hearths, and marine shell samples of Lucina pectinata (Gmelin, 1791) from the same archaeological context (Layer IV) were analyzed. All shell samples were cleaned with ultrapure water and chemically treated with $0.1 \mathrm{M} \mathrm{HCl}$ to remove the outer layer, which could be contaminated. Hydrolysis was done by injecting $\mathrm{H}_{3} \mathrm{PO}_{4}$ with a gas-tight syringe into evacuated vials to obtain $\mathrm{CO}_{2}$. The same procedure to obtain $\mathrm{CO}_{2}$ was adopted for calcite blanks and IAEA C2 carbonate control samples. Charcoal samples went through ABA treatment at $90^{\circ} \mathrm{C}$ with $1 \mathrm{M} \mathrm{HCl}$ acid and $1 \mathrm{M} \mathrm{NaOH}$. Pretreated organic samples were combusted in prebaked quartz tubes with silver wire and cupric oxide at $900^{\circ} \mathrm{C}$ for $3 \mathrm{hr}$ in a muffle oven. The gas was purified by means of dry ice/ethanol traps in the graphitization line (Macario et al. 2013). Graphitization 
was performed using the zinc/titanium hydrate method with iron catalyst (Xu et al. 2007). Torchsealed Pyrex ${ }^{\circledR}$ tubes were heated at $460^{\circ} \mathrm{C}$ for $7 \mathrm{hr}$ in a muffle oven. The graphitized samples were measured in a NEC $250 \mathrm{kV}$ Single Stage Accelerator System (SSAMS). Isotopic fractionation was corrected by measuring the $\delta^{13} \mathrm{C}$ on-line in the accelerator. Background was measured using processed calcite blanks for carbonate samples and processed graphite for organic samples. Graphite and calcite processed blanks yielded average ages of 35 and $38 \mathrm{ka}$, respectively. Average machine background was $\sim 50 \mathrm{ka}$ for the unprocessed graphite. Accuracy was checked by measuring IAEA reference materials within the $2 \sigma$ range of consensus values.

For data analysis, we used the OxCal software v 4.2.3 (Bronk Ramsey and Lee 2013). Measurements of ${ }^{14} \mathrm{C}$ contents of terrestrial/marine samples from the same archaeological context were subjected to an OxCal phase model, a grouping model with the assumption that the events are random samples from a uniform distribution between a start boundary and an end boundary (Buck et al. 1992). The modeled dates use Bayesian analysis (Bayes 1763).

In this preliminary study, a $\Delta \mathrm{R}$ value was calculated by calibrating the terrestrial archaeological samples, land snails termed " $T$ " and charcoal from hearths termed "C," with the SHCal13 atmospheric curve (Hogg et al. 2013) and compared the ${ }^{14} \mathrm{C}$ results for each of the marine archaeological samples termed "M," calibrated with the Marine13 curve (Reimer et al. 2013) within the same phase, considering an undetermined $\Delta \mathrm{R}$ ranging from -500 to $+500{ }^{14} \mathrm{C} \mathrm{yr}$. The software code is presented in Figure 2.

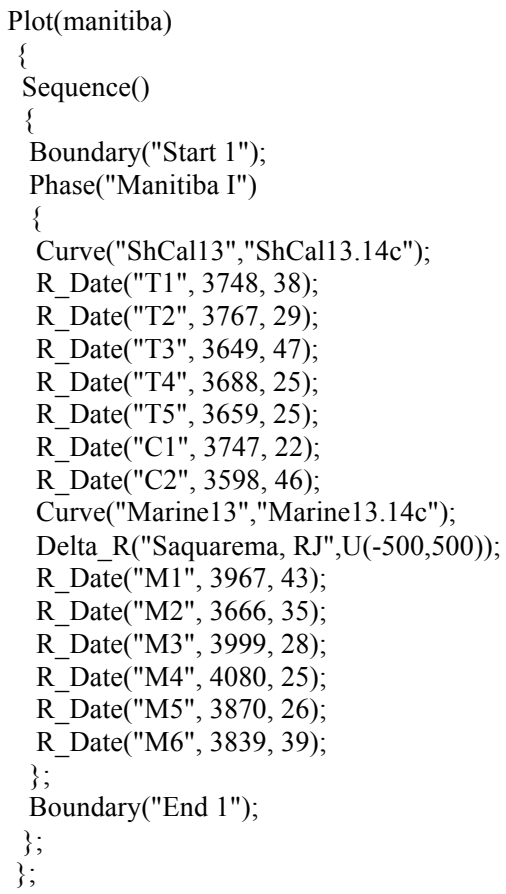

Figure 2 OxCal code for Phase model and $\Delta \mathrm{R}$ determination

\section{RESULTS AND DISCUSSION}

The ${ }^{14} \mathrm{C}$ concentration in modern snail shells was calibrated with the post-bomb atmospheric SH1-2 curve (Hua et al. 2013). The probability distributions for the calibrated dates are presented in Figure 3 and show that this species is in equilibrium with the present-day atmosphere, indicating that 
there is no incorporation of dead carbon in their diet and that such species may provide reliable dating.
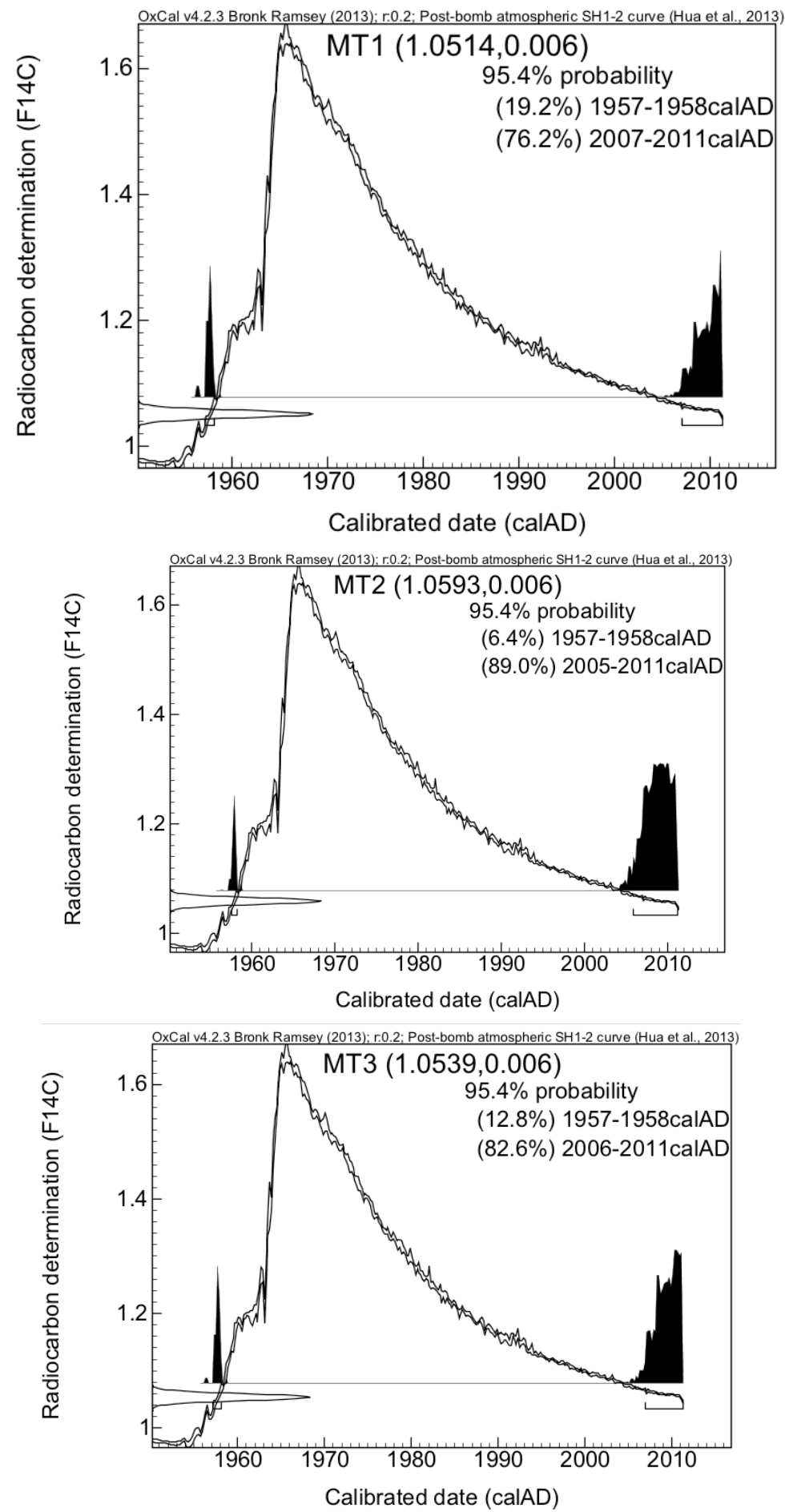

Figure 3 Radiocarbon concentration in the modern terrestrial (MT) mollusks 
Concerning archaeological samples, the results from charcoal are in agreement with those from terrestrial snail shells. Even though there are statistical outliers in the ${ }^{14} \mathrm{C}$ ages of both terrestrial and marine material, the small set of samples has led us to keep them, in an attempt to take into account this variability. Moreover, only after calibration could the results be properly compared; thus, a phase model approach was considered. Table 2 lists the conventional ${ }^{14} \mathrm{C}$ dates, calibrated dates, and modeled dates using OxCal v 4.2.3 for the archaeological samples.

Table $2{ }^{14} \mathrm{C}$ values of archaeological terrestrial and marine samples. $\mathrm{T}$ denotes terrestrial mollusk, $\mathrm{M}$ denotes marine mollusk, and $\mathrm{C}$ denotes charcoal samples.

\begin{tabular}{llllll}
\hline Lab ID & Sample & Sample description & ${ }^{14} \mathrm{C}(\mathrm{yr}$ BP $)$ & $\begin{array}{l}{ }^{14} \mathrm{C} \text { calibrated } \\
\text { age }(\mathrm{BP})\end{array}$ & $\begin{array}{l}{ }^{14} \mathrm{C} \text { modeled } \\
\text { age }(\mathrm{BP})\end{array}$ \\
\hline 140442 & T1 & Thaumastus achilles & $3748 \pm 38$ & $3908-4217$ & $3915-4152$ \\
140443 & T2 & Thaumastus achilles & $3767 \pm 29$ & $3933-4224$ & $3932-4157$ \\
140444 & T3 & Thaumastus achilles & $3649 \pm 47$ & $3728-4084$ & $3770-4086$ \\
140445 & T4 & Thaumastus achilles & $3688 \pm 25$ & $3870-4085$ & $3872-4084$ \\
140446 & T5 & Thaumastus achilles & $3659 \pm 25$ & $3838-4070$ & $3839-4069$ \\
140447 & C1 & Charcoal & $3747 \pm 22$ & $3932-4149$ & $3931-4148$ \\
140448 & C2 & Charcoal & $3598 \pm 46$ & $3699-3977$ & $3716-3982$ \\
140449 & M1 & Lucina pectinata & $3967 \pm 43$ & $3270-4774$ & $3820-4321$ \\
140450 & M2 & Lucina pectinata & $3666 \pm 35$ & $2860-4332$ & $3513-3930$ \\
140451 & M3 & Lucina pectinata & $3999 \pm 28$ & $3324-4795$ & $3865-4345$ \\
140452 & M4 & Lucina pectinata & $4080 \pm 25$ & $3381-4839$ & $3971-4417$ \\
140453 & M5 & Lucina pectinata & $3870 \pm 26$ & $3109-4608$ & $3692-4158$ \\
140454 & M6 & Lucina pectinata & $3839 \pm 39$ & $3060-4561$ & $3655-4136$ \\
\hline
\end{tabular}

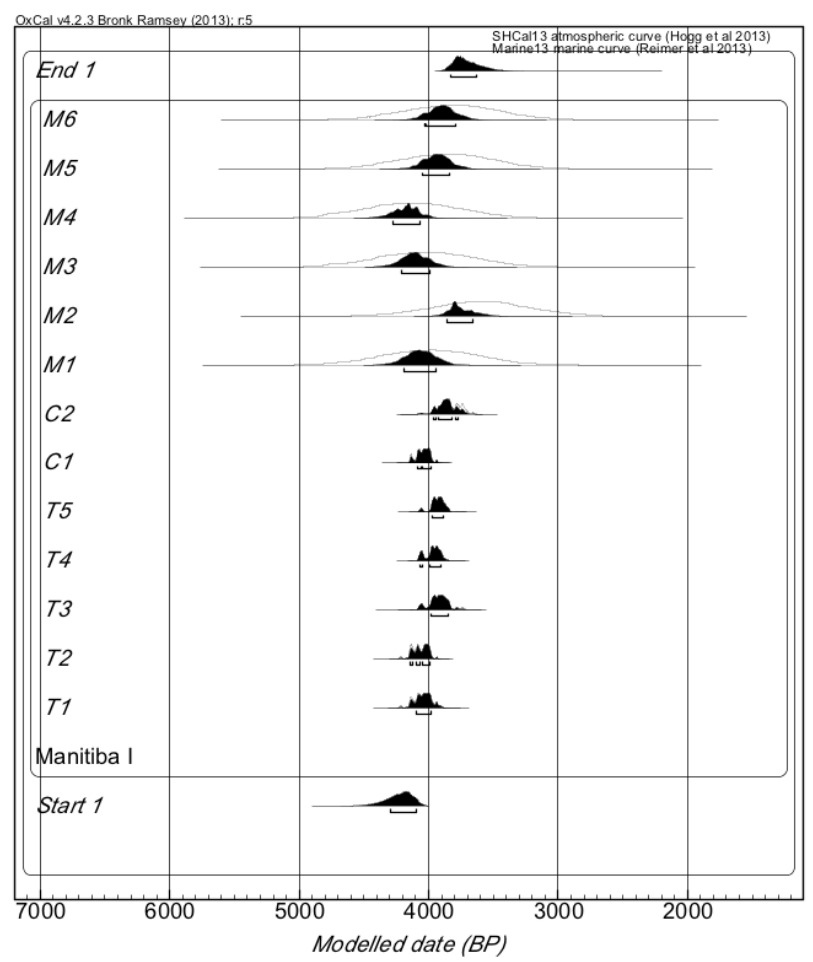

Figure 3 Modeled dates of marine and terrestrial paired samples from the same archaeological context using OxCal v 4.2.3 (Bronk Ramsey and Lee 2013). 
Calibrated modeled dates for terrestrial and marine samples leaving $\Delta \mathrm{R}$ undetermined within a $1000{ }^{14} \mathrm{C}$ yr range can be observed in Figure 3. Probability distributions for the beginning and ending of the phase are also shown. Based on this model, a local reservoir effect ( $\triangle \mathrm{R}$ value) of $-82 \pm$ $71{ }^{14} \mathrm{C}$ yr was calculated from the Manitiba I shellmound (Figure 4).

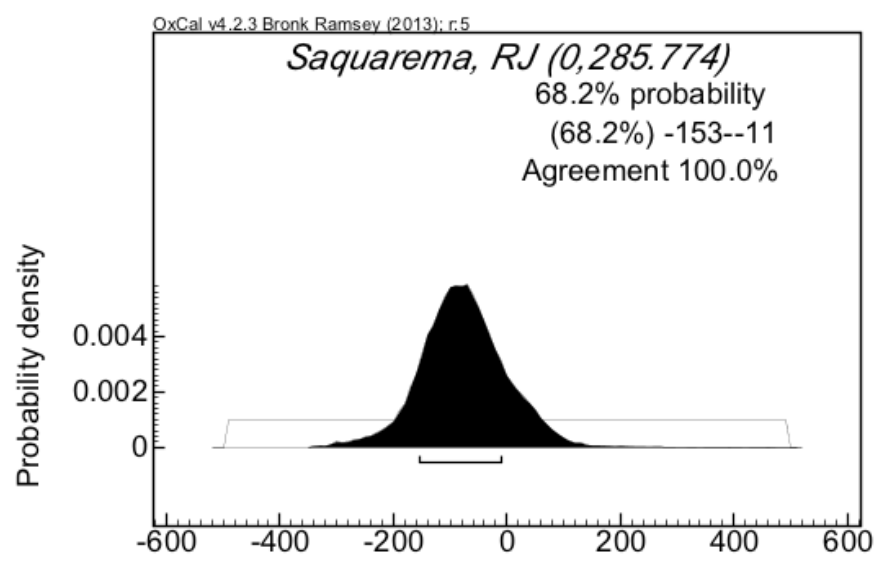

Figure $4 \Delta \mathrm{R}$ value calculated with terrestrial/marine samples from Manitiba I shellmound.

The negative value for the $\Delta \mathrm{R}$ correction found in this article decreases the total correction for the MRE in the studied region. Saquarema is affected by a well-known seasonal upwelling effect (Ikeda et al. 1974) that would yield positive values for the $\Delta \mathrm{R}$ correction. However, the material sampled in this work could be influenced by freshwater due to the proximity of the lagoon. The result is also in agreement with the other results obtained for this region (Alves et al. 2015; Macario et al. 2015). These results show that it is possible to determine reliable $\Delta \mathrm{R}$ values using terrestrial/marine samples, from an archaeological site, that were found in the same depositional context. Also, the study shows that there is no incorporation of dead carbon in the T. achilles diet, and this species may provide reliable dating.

\section{CONCLUSION}

Quantifying the marine reservoir effect provides a better understanding of local coastal processes. In the southeastern coast of Brazil, there are many archaeological shellmounds dating from 5 to $2 \mathrm{kyr}$ cal BP that contain terrestrial and marine remains in the same archaeostratigraphic context. However, charcoal is not usually as thoroughly distributed as shells and, when this is the case, terrestrial gastropods with the potential to yield reliable ${ }^{14} \mathrm{C}$ dates, such as T. achilles, can be used instead. A $\Delta \mathrm{R}$ value of $-82 \pm 71{ }^{14} \mathrm{C}$ yr was calculated for the Saquarema region from Manitiba I shellmound terrestrial/marine paired samples using an OxCal phase model.

\section{ACKNOWLEDGMENTS}

The authors would like to thank Brazilian financial agencies CNPq (Conselho Nacional de Desenvolvimento Científico e Tecnológico), CAPES (Coordenação de Aperfeiçoamento de Pessoal de Nível Superior), FAPERJ (Fundação de Amparo à Pesquisa do Estado do Rio de Janeiro), and PRONEX (Programa de Apoio a Núcleos de Excelência) for their support. 


\section{REFERENCES}

Alves E, Macario K, Souza R, Aguilera O, Goulart AC, Scheel-Ybert R, Bachelet C, Carvalho C, Oliveira F, Douka K. 2015. Marine reservoir corrections on the southeastern coast of Brazil: paired samples from the Saquarema shellmound. Radiocarbon 57(4). doi:10.2458/azu_ rc.57.18404.

Angulo RJ, Souza MC, Reimer PJ, Sasaoka SK. 2005. Reservoir effect of the southern and southeastern Brazilian coast. Radiocarbon 47(1):67-73.

Ascough PL, Cook GT, Dugmore AJ, Barber J, Higney E, Scott EM. 2004. Holocene variations in the Scottish marine radiocarbon reservoir effect. Radiocarbon 46(2):611-20.

Ascough PL, Cook GT, Dugmore AJ. 2009. North Atlantic marine ${ }^{14} \mathrm{C}$ reservoir effects: implications for late-Holocene chronological studies. Geochronology 4(3):171-80.

Bayes TR. 1763. An essay towards solving a problem in the doctrine of chances. Philosophical Transactions of the Royal Society 53:370-418.

Barnhardt MC. 1992. Acid-base regulation in pulmonate molluscs. The Journal of Experimental Zoology 263:120-6.

Breure ASH. 1979. Systematics, phylogeny and zoogeography of Bulimulinae (Mollusca). Zoologische Verhandelingen Leiden 168:1-215.

Bronk Ramsey C, Lee S. 2013. Recent and planned developments of the program OxCal. Radiocarbon 55(2-3):720-30.

Buck CE, Litton CD, Smith AFM. 1992. Calibration of radiocarbon results pertaining to related archaeological events. Journal of Archaeological Science 19(5):497-512.

Culleton BJ. 2006. Implications of a freshwater radiocarbon reservoir correction for the timing of late Holocene settlement of the Elk Hills, Kern County, California. Journal of Archaelogical Sciences 33(9):1331-9.

Culleton BJ, Kennett DJ, Ingram BL, Erlandson JM, Southon JR. 2006. Intrashell radiocarbon variability in marine mollusks. Radiocarbon 48(3):387-400.

Eastoe CJ, Fish S, Fish P, Gaspar MD, Long A. 2002. Reservoir corrections for marine samples from the South Atlantic coast, Santa Catarina State, Brazil. Radiocarbon 44(1):145-8.

Evin J, Marechal J, Pachiaudi C, Puissegur JJ. 1980. Conditions involved in dating terrestrial shells. $R a-$ diocarbon 22(2):545-55.

Fernandes R, Bergemann S, Hartz S, Grootes PM, Nadeau M-J, Melzner A, Rakowski A, Hüls M. 2012. Mussels with meat: bivalve tissue-shell radiocarbon age differences and archaeological implications. $R a$ diocarbon 54(3-4):953-65.

Goodfriend GA. 1987. Radiocarbon age anomalies in shell carbonate of land snails from semi-arid areas. Radiocarbon 29(2):159-67.

Goodfriend GA, Hood DG. 1983. Carbon isotope analysis of land snail shells: implications for carbon sources and radiocarbon dating. Radiocarbon 25(3):810-30.

Goodfriend GA, Stipp JJ. 1983. Limestone and the problem of radiocarbon dating of land-snail shell carbonate. Geology 11:575-7.

Goodfriend GA, Ellis GL, Toolin LJ. 1999. Radiocarbon age anomalies in land snail shells from Texas: ontogenetic, individual and geographic patterns of variation. Radiocarbon 41(2):149-56.

Gordon JE, Harkness DD. 1992. Magnitude and geographic variation of the radiocarbon content in Antarctic marine life: implications for reservoir corrections in radiocarbon dating. Quaternary Science Reviews 11(7-8):697-708.

Hogg AG, Hua Q, Blackwell PG, Niu M, Buck CE, Guilderson TP, Heaton TJ, Palmer JG, Reimer PJ, Reimer RW, Turney CSM, Zimmerman SRH. 2013. SHCal13 Southern Hemisphere calibration, 0-50,000 years cal BP. Radiocarbon 55(4):1889_ 903

Hua Q, Barbetti M, Rakowski AJ. 2013. Atmospheric radiocarbon for the period 1950-2010. Radiocarbon 55(4):2059-72.

Hughen KA, Baillie MGL, Bard E, Beck JW, Bertrand CJH, Blackwell PG, Buck CE, Burr GS, Cutler KB, Damon PE, Edwards RL, Fairbanks RG, Friedrich M, Guilderson TP, Kromer B, McCormac G, Manning S, Bronk Ramsey C, Reimer PJ, Reimer RW, Remmele S, Southon JR, Stuiver M, Talamo S, Taylor FW, van der Plicht J, Weyenmeyer CE. 2004. Marine04 marine radiocarbon age calibration, 0-26 cal kyr BP. Radiocarbon 46(3):1059-86.

Ikeda Y, de Miranda LB, Rock NJ. 1974. Observations on stages of upwelling in the region of Cabo Frio (Brazil) as conducted by continuous surface temperature and salinity measurements. Boletim Instuto Oceanográfico, São Paulo 23:33-46.

Kennett DJ, Ingram BL, Erlandson JM, Walker P. 1997. Evidence for temporal fluctuations in marine radiocarbon reservoir ages in the Santa Barbara Channel, Southern California. Journal of Archaeological Science 24(11):1051-9.

Kneip LM. 2001. O sambaqui de Manitiba I e outros sambaquis de Saquarema, RJ. Documentos de Trabalho (5) Série Arqueologia, Departamento de Antropologia, Museu Nacional, Universidade Federal do Rio de Janeiro. $91 \mathrm{p}$.

Macario KD, Gomes PRS, Anjos RM, Carvalho C, Linares R, Alves EQ, Oliveira FM, Castro MD, Chanca IS, Silveira MFM, Pessenda LCR, Moraes LMB, Campos TB, Cherkinsky A. 2013. The Brazilian AMS Radiocarbon Laboratory (LAC-UFF) and the intercomparison of results with CENA and UGAMS. Radiocarbon 55(2-3):325-30.

Macario KD, Souza RCCL, Trindade DC, Decco J, Lima TA, Aguilera OA, Marques AN, Alves EQ, Oliveira FM, Chanca IS, Carvalho C, Anjos RM, Pamplona 
FC, Silva EP. 2014. Chronological model of a Brazilian Holocene shellmound (Sambaqui da Tarioba, Rio de Janeiro, Brazil). Radiocarbon 56(2):489-99.

Macario KD, Souza RCCL, Aguilera OA, Carvalho C, Oliveira FM, Alves EQ, Chanca IS, Silva EP, Douka K, Decco J, Trindade DC, Marques AN, Anjos RM, Pamplona FC. 2015. Marine reservoir effect on the Southeastern coast of Brazil: results from the Tarioba shellmound paired samples. Journal of Environmental Radioactivity 143:14-9.

Nadal de Masi MA. 2001. Pescadores coletores da costa sul do Brasil. Pesquisas Antropologia 57:1-136.

Petchey F, Ulm S, David B, McNiven I, Asmussen B, Tomkins H, Dolby N, Aplin K, Richards T, Rowe C, Leavesley M, Mandui H. 2013. High-resolution radiocarbon dating of marine materials in archaeological contexts: radiocarbon marine reservoir variability between Anadara, Gafrarium, Batissa, Polymesoda spp. and Echinoidea at Caution Bay, Southern Coastal Papua New Guinea. Archaeological and Anthropological Sciences 5(1):69-80.

Pigati JS, Rech JA, Nekola JC. 2010. Radiocarbon dating of small terrestrial gastropod shells in North America. Quaternary Geochronology 5:519-32.

Quarta G, Romaniello L, D’Elia M, Mastronuzzi G, Calcagnile L. 2007. Radiocarbon age anomalies in preand post-bomb land snails from the coastal Mediterranean basin. Radiocarbon 49(2):817-26.

Rakovan MT, Rech JA, Pigati JS, Nekola JC, Wiles GC. 2013. An evaluation of Mesodon and other larger terrestrial gastropod shells for dating late Holocene and historic alluvium in the Midwestern USA. Geomorphology 193:47-56.

Rech JA, Nekola JC, Pigati JS. 2012. Radiocarbon ages of terrestrial gastropods extend duration of ice-free conditions at the Two Creeks forest bed, Wisconsin, USA. Quaternary Research 77(2):289-92.

Reimer PJ, Bard E, Bayliss A, Beck JW, Blackwell PG, Bronk Ramsey C, Grootes PM, Guilderson TP, Haflidason H, Hajdas I, Hatté C, Heaton TJ, Hoffmann DL, Hogg AG, Hughen KA, Kaiser KF, Kromer B, Manning SW, Niu M, Reimer RW, Richards DA, Scott EM, Southon JR, Staff RA, Turney CSM, van der Plicht J. 2013. IntCal13 and Marine13 radiocarbon age calibration curves $0-50,000$ years cal BP. Radiocarbon 55(4):1869-87.

Romaniello L, Quarta G, Mastronuzzi G, D'Elia M, Calcagnile L. 2008. ${ }^{14} \mathrm{C}$ age anomalies in modern land snails shell carbonate from southern Italy. Quaternary Geochronology 3(1-2):68-75.

Rubin M, Likins RC, Berry EG. 1963. On the validity of radiocarbon dates from snail shells. Journal of $\mathrm{Ge}$ ology 71(1):84-9.
Russell N, Cook GT, Ascough PL, Dugmore AJ. 2010. Spatial variation in the marine radiocarbon reservoir effect throughout the Scottish post-Roman to late Medieval period: North Sea values (500-1350 BP). Radiocarbon 52(3): 1166-81.

Soares AMM, Dias JMA. 2006. Coastal upwelling and radiocarbon-evidence for temporal fluctuations in ocean reservoir effect off Portugal during the Holocene. Radiocarbon 48(1):45-60.

Soares AMM, Dias JMA. 2007. Reservoir effect of coastal waters off western and northwestern Galicia. Radiocarbon 49(2):925-36.

Stott LD. 2002. The influence of diet of the $\delta^{13} \mathrm{C}$ of shell carbon in the pulmonate snail Helix aspersa. Earth and Planetary Letters 195(3-4):248-59.

Stuiver M, Braziunas T. 1993. ${ }^{14} \mathrm{C}$ ages of marine samples to 10,000 BC. Radiocarbon 35(1):137-89.

Stuiver M, Pearson GW, Braziunas T. 1986. Radiocarbon age calibration of marine samples back to 9000 cal yr BP. Radiocarbon 28(2B):980-1021.

Tamers MA. 1970. Validity of radiocarbon dates on terrestrial snail shells. American Antiquity 35(1):94100.

Xu B, Gu Z, Han J, Hao Q, Lu Y, Wang L, Wu N, Peng Y. 2011. Radiocarbon age anomalies of land snail shells in the Chinese Loess Plateau. Quaternary Geochronology 6(3-4):383-9.

Xu X, Trumbore SE, Zheng S, Southon JR, McDuffee KE, Luttgen M, Liu JC. 2007. Modifying a sealed tube zinc reduction method for preparation of AMS graphite targets: reducing background and attaining high precision. Nuclear Instruments and Methods in Physics Research B 259(1):320-9.

Yanes Y, Romanek CS, Molina F, Cámara JA, Delgado A. 2011. Holocene paleoenvironment (7,200-4,000 cal. years BP) of the Los Castillejos archaeological site (SE Spain) as inferred from stable isotopes of land snail shells. Quaternary International 244:6775.

Yanes Y, Gutiérrez-Zugasti I, Delgado A. 2012. Lateglacial to Holocene transition in northern Spain deduced from land-snail shelly accumulations. Quaternary Research 78(2):373-85.

Yates TJS. 1986. Studies of non-marine mollusks for the selection of shell samples for radiocarbon dating. Radiocarbon 28(2A):457-63.

Zaarur S, Olack G, Affek HP. 2011. Paleo-environmental implication of clumped isotopes in land snail shells. Geochimica et Cosmochimica Acta 75(22):6859-69.

Zhou W, Head WJ, Wang F, Donahue D, Jull AJT. 1999. The reliability of AMS radiocarbon dating of shells from China. Radiocarbon 41(1):17-24. 